\title{
МОДЕЛИРОВАНИЕ УПРУГИХ ВОЛН С ЦЕЛЬЮ ОБОСНОВАНИЯ И ОПТИМИЗАЦИИ СЕЙСМИЧЕСКИХ ИССЛЕДОВАНИЙ
}

Череповский А.В., Лаптев А.П., Белозерова Н.С.

(Input Output Inc. Геомен Пермнефтегеофизика)

\section{Краткое содержание}

В прошлом, массивы синтетинеских сейсмических данных чате всего создавались для огробования новых алгоритмов миграции и инверсии. Наша компания использует как лучевое, так и полноволновое (конечно-разностное) моделирование упругих волн, в первую очередь, дпя обоснования многоволновых сейсмических исследований. Мы построили упругую модель мощного верхнедевонского рифа, отстреляли профиль 2 Д длиной $12 \mathrm{kм}$, а затөм обработали и проинтерпретировали синтетнческие данные. Моделируемая рифогенная постройка отображается достаточно отчетливо на мигрированных разрезах PP и PS. Аномальные области пониженных значений параметра «гамма» ( $\mathrm{Vp} / \mathrm{Vs})$, рассчитанные для различных временных интервалов между отражениями от пород верхнего девона, могут стать хоропти поисковым гризнаком для выявления рғфогенных построек. Рифовые огложения жетко выделяются на кросс-плоте параметра «гамма» и акустических импедансов.

\section{Введение}

Одно из самых грандиозных модельных исследований было выполнено компанией $\mathrm{GX}$ Technology в конще 2002 г. [1]. Конечно-разностное моделирование для обновленной упругой модели Мармузи заяяло пять месяцев на кластере Хьюстонского университета (что было бы эквивалентно 8 годам на персональном компьотере!).

Безусловно, полноволновое решение позволяет получить гораздо более реальные сейсмограммы ОПВ. Однако, волновое поле на конечноразностных синтеткческих сейсмограммах - особенно при многослойной и низкоскоростной ВЧР может быть настолько спожным, что без подсказки, которую дает лучевое моделирование, очень сложно выделить целевые стражения, правильно выбрать процедуры подавления крапных волн и многоканальные фильтры. Пюэтому лучевое моделирование сохраняет свою актуальность [2] и. в определенных случаях дополньет полновопновое моделирование нагример, при оценке апертуры миграцин и определении необходимой площади сейсморазведочных paбoт.

\section{Результаты}

Для шбоснования многоволновой сейсморазведки на верхнедевонские рифы, распространенные в Волго-Уральском регионе, мы постронпи толстослоистую упругую модель рифа (Рис.1) и отстреляли профиль длиной $12 \mathrm{kм}$ с системой наблюдений, одингцковой дия туучевого и полноводнового моделироваг пия. А именно, мы выбра:ии центральную систему наблюдений с шагом пунктов приема $25 \mathrm{M}$ шаг ом ПВ, равным 100 м. Для обеспечения точного скор үостного анализа в условиях высокоскоростного разреза мы выбрали макскмальное расстояние источник-приемник, равное 3500 м.

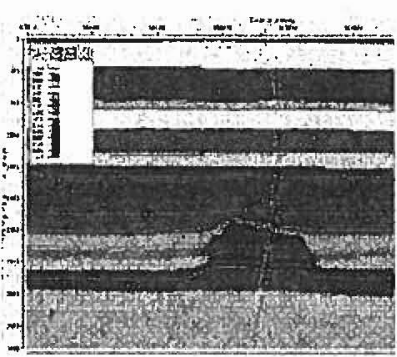

a)

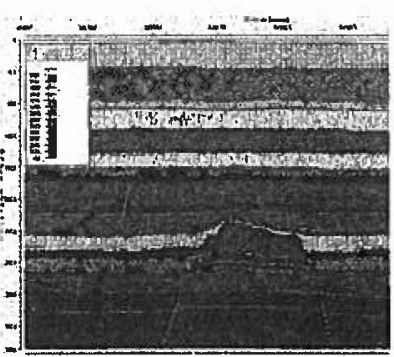

6)
Рис.1. Модель девонского рифа в скоростях продольных (а) и поперечных (6) волн.

Обработка синтетических данных (вертикальная и горизонтальная компоненты) включала временную миграцию Кирхгофа до суммирования. Основные преимущества применения комплекса волн разного типа заключены, с одной стороны, в независимости результатов, получаемых при применении волн разного типа, а с другой - в возможности получения дополнительньх параметров, позволяющих более полно изучить исследуемый объект. Разрезы интервальных значений $\gamma(\mathrm{Vp} / \mathrm{Vs})$ были построены как для интервала отражений от всего рифового массива, так и для его верхней части. В обонх случаях наблюдается (заданное в модели) аномальное понижение величины $\gamma$ в зоне развития рифогенных фаций. По результатам псевдоакустического преобразования в двух интервалах были определены средние значения имтедансов $\left(\mathrm{ID}=\mathrm{Vp}^{*} \mathrm{\rho}\right)$ и выполнен анализ зависимости величины $\gamma$ от ID. Рифовые отложения четко выделяются на кросс-плоте «гамма» и акустических импедансов.

\section{Заключение}

Результаты моделирования показывают, что многоволновая сейсморазведка обладает большим потенциалом при разведке подобных карбонатных построек и рифов. Для надежной привязки различных типов волн и оценки их физических параметров наземные работы 3 С рекомендуется комплексировать с ВСП и ВАK.

\section{ЛИТЕРАТУРА}

1. Murtin, G. Wiley, R. \& Marfurt, K. 2006. Marmousi2: An elastic upgrade for Marmousi. The Leading Edge, February 2002.

2. Тихонов А.А., 2001, Применение и развитие идей Е.И.Гатьперина при проведении многокомпонентных наблюдений, Гальперинские чтения, Москва 2001. 